DIGITAL COMMONS
@ UNIVERSITY OF SOUTH FLORIDA

Journal of African Conflicts and

Peace Studies

Volume 1

Issue 2 Genocide: Critical Issues

Article 7

September 2009

\title{
Genocide, Denial, and Domination: Armenian-Turkish Relations from Conflict Resolution to Just Transformation
}

Henry C. Theriault

Worcester State College, Massachusetts, htheriault@worcester.edu

Follow this and additional works at: https://digitalcommons.usf.edu/jacaps

\section{Recommended Citation}

Theriault, Henry C. (2009) "Genocide, Denial, and Domination: Armenian-Turkish Relations from Conflict Resolution to Just Transformation," Journal of African Conflicts and Peace Studies: Vol. 1: Iss. 2, 82-96. DOI: http://dx.doi.org/10.5038/2325-484X.1.2.5

Available at: https://digitalcommons.usf.edu/jacaps/vol1/iss2/7

This Article is brought to you for free and open access by the Open Access Journals at Digital Commons @ University of South Florida. It has been accepted for inclusion in Journal of African Conflicts and Peace Studies by an authorized editor of Digital Commons @ University of South Florida. For more information, please contact digitalcommons@usf.edu. 


\title{
Journal of African Conflicts and Peace Studies
}

\section{GENOCIDE, DENIAL, AND DOMINATION: ARMENIAN-TURKISH RELATIONS FROM CONFLICT RESOLUTION TO JUST TRANSFORMATION}

\begin{abstract}
Henry C. THERIAULT
Abstract: This article presents a critical analysis of the general "conflict resolution" approach for improving Turkish-Armenian relations, the latter of which completely broke apart as a result of the Ottoman Turk Genocide of the Armenians (1915-1923). In doing so, it examines past and present Armenian-Turkish relations underlying the approach. Ultimately, the author argues that the forms of the "conflict resolution" model typically proposed and pursued cannot address the root causes of the problems inherent in Turkish-Armenian relations and thus cannot succeed in resolving those problems. The author concludes with recommendations that he believes could lead toward a meaningful resolution of the Turkish-Armenian issue over the Armenian Genocide.
\end{abstract}

Introduction

In the past decade, there has been much discussion among Armenians and progressive Turks, as well as interested third parties, about how to resolve the ongoing tension that has resulted from the Ottoman Empire's 1915 Armenian Genocide. The tension has manifested itself in various ways: the repression of the small Armenian minority in Turkey; a multi-million dollar Turkish denial campaign to cover up the history of the Armenian Genocide; Armenian assassinations in the 1970s and 1980s of a number of Turkish government officials; the 2007 assassination of Turkish Armenian activist Hrant Dink by Turkish extremists probably with governmental support; a twodecade old blockade by Turkey of the Armenia Republic's border; Turkey's military support for Azerbaijan in its war against Armenian separatists in Karabakh; and efforts by Armenians in the United States, France, and elsewhere to get their countries to officially recognize the Armenian Genocide, call on Turkey to acknowledge it, and prevent Turkey from membership in the European Union until it does recognize the Armenian Genocide.

The tension has been presented as either an enduring ethnic conflict that is seen as the consequence either of a legitimately contested view of the events of 1915 -- that is, whether they constituted genocide or not, whether Armenians share equal responsibility for the violence, whether Turks were victims, etc. - or of a persistent Turkish unwillingness to acknowledge that the Ottoman Empire did commit a genocide against Armenians. Individuals and groups adopting either formulation have pushed 


\section{Journal of African Conflicts and Peace Studies}

for various conflict resolution processes to address the tension. Some of these efforts have resulted in the development of positive relations among many Armenians and the growing ranks of progressive Turks -- both outside Turkey, and, more recently, inside of Turkey -- who recognize, at least, the historical injustice at work in Turkish relations with Armenians.

This past year, the Turkish and Armenian governments have even taken tentative steps toward some kind of discussion of the tension (including, for instance, a recent visit by the Turkish president to the Armenian Republic to watch a Turkish-Armenian soccer game). At the same time, these developments have not affected Turkish governmental policy toward Armenians inside and outside of Turkey nor ended the denial campaign. The upshot is that the concrete reality of a strong tension remains.

This article offers a critical analysis of the general "conflict resolution" approach supported by many who wish for improved Turkish-Armenian relations. It examines the usual view of past and present Armenian-Turkish relations underlying the approach. Based on this, the article argues that the forms of "conflict resolution" model typically proposed and pursued cannot address the root causes of the problems in TurkishArmenian relations and thus cannot succeed in resolving those problems. It further argues that such approaches have, in fact, the potential to exacerbate the problems. It concludes with a suggestion of the path that should be followed toward a meaningful resolution of the Turkish-Armenian issue over the Armenian Genocide.

\section{The Armenian Genocide}

Beginning in early 1915, the Ottoman Empire's government, by then run autocratically by the Committee of Union and Progress (CUP), carried out a genocide against its Armenian minority of 2.5 million, as well as against the smaller minority populations of Assyrians and Pontian Greeks. The main phase of the Armenian Genocide consisted of four segments. First, the Ottoman government disarmed and eventually killed directly -- or worked to death -- the approximately 250,000 Armenian men in the Ottoman military. Because World War I was being fought in and in close proximity to Ottoman territory, these soldiers were a potentially armed and trained defense for the Empire's Armenian population. Their destruction not only was itself a major step in the elimination of the Armenian population but also removed the possibility of widespread military defense against the genocidal violence soon to be unleashed against the general Armenian population. Second, on April 24, 1915, the Ottoman government rounded up hundreds of leading Armenian political, intellectual, cultural, and religious 


\section{Journal of African Conflicts and Peace Studies}

leaders, killing virtually all of them. This removed the leadership from the networks and institutions with national and international reach, at once preventing a coordinated Armenian response to the Genocide and limiting the connections between Armenians and the outside world. Third, the Ottoman government began systematically deporting the general Armenian population (mainly women, children, and the elderly) from their homes, generally village by village and from some urban areas where scrutiny by foreigners was minimal. Deported Armenians were typically forced onto death marches with almost no possessions, to be starved, brutalized, and killed.

Deportees were preyed upon by local Turks and Kurds, murdered, kidnapped into (sexual and other types of) slavery, robbed even of their clothes, and more. Special Organization units comprised of released violent criminals operated as mobile killing squads, attacking caravans as well. Groups were often marched around week after week until violence, starvation, and disease exacted heavy tolls. In the fourth segment, surviving Armenians arrived in the Syrian Desert, especially the area around Der el Zor, where they were held in barren places as they died or were killed, for instance, by interring Armenians in underground caves and immolating them using a flammable liquid such as kerosene. It is estimated that more than 1 million Armenians died in this main phase of the Genocide, and uncounted numbers of (1) children were forcibly Turkified and taken into Turkish homes either as children or domestic slaves and (2) women and girls were taken into sexual or domestic slavery or forcibly converted and married to Turkish men. Some of these escaped in the years following this period. ${ }^{1}$

After the end of World War I in 1918, a smaller second phase of the Armenian Genocide was executed by nationalist forces led by Kemal Ataturk. These forces killed thousands of Armenian survivors who, believing that the end of CUP rule meant an end to killings of Armenians had returned to their homes to try to rebuild their lives. In addition, Ataturk's forces attacked the newly established Armenian Republic and by 1920 conquered the bulk of it and annexed the lands to Turkey (most of which were Ottoman lands given to Armenians because of the perceived need for Armenian

\footnotetext{
${ }^{1}$ For general accounts of the main phase of the Armenian Genocide, see Richard G. Hovannisian "The Historical Dimensions of the Armenian Question, 1878-1923," in The Armenian Genocide in Perspective, ed. By Richard Hovannisian (New Brunswick, NJ: Transaction Books, 1986), pp. 19-41, and Vahakn N. Dadrian, The History of the Armenian Genocide: Ethnic Conflict from the Balkans to Anatolia to the Causasus, 3d rev. ed. (Providence, Rl: Berghahn Books, 1997). For a comprehensive set of primary eyewitness accounts of the Genocide, see United States Official Records on the Armenian Genocide, 1915-1917, compiled with an introduction by Ara Sarafian (Princeton: Gomidas Institute, 2004).
} 


\section{Journal of African Conflicts and Peace Studies}

political independence from Turkey after the Genocide), killing many additional Armenians in the process. ${ }^{2}$

There are different views of the causes of the Armenian Genocide, but all views more or less agree that the essential ingredient was the extreme Turkish ultra-nationalism that came to dominate the Young Turks who had seized control of the Ottoman government after deposing Sultan Abdul Hamid II in 1908. Prior to the 1908 revolution, the Ottoman Empire was organized by a millet system that allowed Muslims full rights and accorded second-class subject status to non-Muslims including Armenians, Greeks, Assyrians, and Jews. They were denied various basic legal rights (such as testifying against Muslims in law courts), prevented from holding certain kinds of jobs (such as serving in the military), forced to pay higher taxes, and unable to participate in the political process. This differential status went beyond legal discrimination: members of the lower-status millets were often targeted for violence, theft, rape, and degradations that were unpunished or punished at lower rates and levels than violations against Muslims. Even mass violence against and oppression of minority groups was tolerated by the central government and ultimately perpetrated by that government, culminating in the 1894-1896 Massacres in which Sultan Abdul Hamid II's regular and auxiliary forces killed more than 100,000 and possibly more than 200,000 Armenians.

Initially (in 1908), the Young Turks, with support from Armenian and other political groups, proclaimed a pluralistic liberal state in which all residents, regardless of ethnicity and religion, could be full citizens. While this remained the official stance of the government as late as 1915, in reality, a subset of Young Turks forming the CUP took control of the government and society. They were organized around the view that the Ottoman Empire should be a Turkish national state, and only Turks or those who could be assimilated into Turkish identity had a place in that state. Some Greeks could be expelled to Greece, but not all, and Assyrians and Armenians could not be expelled en masse anywhere. They could only be eliminated by forced assimilation and murder, and forced assimilation could only be used for a relatively small number. The result was genocide.

\footnotetext{
2 On the second phase of the Genocide, see for example Levon Marashlian, "Finishing the Genocide: Cleansing Turkey of Armenian Survivors, 1920-1923," in Remembrance and Denial: The Case of the Armenian Genocide, ed. Richard Hovannisian (Detroit: Wayne State University Press, 1999), pp. 11345, and Dadrian, "The Kemalist Thrust against Russian Armenia," in The History of the Armenian Genocide, pp. 356-74.
} 


\section{Journal of African Conflicts and Peace Studies}

After the CUP leadership was removed from power at the end of World War I, there were trials of some perpetrators. Some were convicted and sentenced. As the nationalists under Ataturk gained power, however, the trial process ground to a halt with only very partial and minor achievements. In addition, convicted prisoners were released. ${ }^{3}$ Soon, many of those involved in the Armenian Genocide took up roles in developing the new Turkish Republic's political and military institutions.

\section{Denial}

Even as the Genocide unfolded, the CUP engaged in a campaign of denial, coveringup the extent of their actions against Armenians and attributing violence to efforts by the government to defend itself against Armenian rebellions and Armenian support for Russia, the Empire's enemy in World War I. While in the immediate post-CUP period, the new government did acknowledge the mass extermination of Armenians; but with the ascension of Ataturk's nationalists, subsequent governments first ended references to the Genocide and later actively denied that a genocide had occurred. It took until the 1960s for the global Armenian diaspora, mainly consisting of refugees from the Genocide and their progeny, to recover sufficiently to be able to challenge this denial publically. At the same time, there developed enough freedom in the Soviet Union that popular pressure in the Armenian SSR for commemoration of the Genocide had some success.

Since the 1970s, the Turkish government's denial campaign has been extensive. In the United States alone, to prevent US recognition of the Genocide, it expends significant diplomatic resources, even to the point of ambassadorial visits to state governments in the United States. It also pays millions for the lobbying of US legislators. The Turkish government and private supporters also promote various efforts in journalistic circles as well as academia, including the funding of university positions for deniers. Within Turkish universities as well as in the American academy and media, the Turkish government has developed a well-oiled propaganda machine that continually disseminates a falsified view of history and challenges attempts to present the true facts of history to academic and popular audiences. ${ }^{4}$ Even the AntiDefamation League, a leading Jewish civil rights organization, has actively lobbied US

\footnotetext{
${ }^{3}$ See Dadrian, "The Recourse to the Machinery of Turkish Justice," in The History of the Armenian Genocide, pp. 317-43.

${ }^{4}$ For an overview of the history of the Turkish denial campaign, see Hovannisian, "The Armenian Genocide and Patterns of Denial," in The Armenian Genocide in Perspective, pp. 111-33.
} 


\section{Journal of African Conflicts and Peace Studies}

political leaders on behalf of the Turkish government's denial position. While in more recent years more and more scholars from around the world -- who are neither Armenian nor Turkish -- have gone on record recognizing the Armenian Genocide, and thus a consensus among credible scholars has developed, the Turkish denial campaign continues to undermine broad knowledge of and credibility for the historical truth. Deniers use a number of different arguments that, unfortunately, prove effective in fooling people. ${ }^{5}$

\section{Conflict Resolution Models}

There are two prevailing views of contemporary Armenian-Turkish relations. The first is that Armenians and Turks generally have incompatible views of the history of their interactions, with Armenians claiming a genocide and Turks disputing this claim. The incompatibility has produced a conflict. The second is that Turkish denial is producing tension with Armenians.

The first view is presented in a number of forms, from a number of sources. Some deniers of the Armenian Genocide adopt this view as a way of arguing that the facts of the history of the 1915 are either somewhere between the two "extreme" positions of Turkish denial and the true facts as determined by a host of Armenian and nonArmenian scholars, or impossible to settle because interpretations of history are always subjective and so we have a "Turkish" view and an "Armenian" view with neither no more valid than the other. Initiatives such as the ill-fated "Turkish Armenian Reconciliation Committee" (TARC) were based on the idea that resolution of the tension between Armenians and Turks could be accomplished through a negotiated settlement of the various issues each side perceived as important, including the history of 1915.6 Similarly, Princeton University denier Norman Itzkowitz argues that the tension between Armenians and Turks derives mainly from the "victim mentality" of

\footnotetext{
${ }^{5}$ For detailed typologies and analyses of the different arguments used by deniers of the Armenian Genocide, see Richard Hovannisian, "Denial of the Armenian Genocide in Comparison with Holocaust Denial," in Remembrance and Denial: The Case of the Armenian Genocide, ed. Hovannisian (Detroit: Wayne State University Press, 1999), pp. 201-36; George M. Aghjayan, "Genocide Denial: The Armenian and Jewish Experiences Compared" (Worcester: Armenian National Committee of Central Massachusetts, 1998); and Henry C. Theriault, "An Analytical Typology of Arguments Denying Genocides and Related Mass Human Rights Violations" (Comparative Genocide Studies [University of Tokyo] Volume 1, 2004), pp. 78-101.

${ }^{6}$ For an elucidating proponent's view of TARC, see David L. Phillips, Unsilencing the Past: Track Two Diplomacy and Turkish-Armenian Reconciliation (New York: Berghahn Books, 2005).
} 


\section{Journal of African Conflicts and Peace Studies}

Armenians that causes them to view the events of 1915 as a great injustice and to refuse to have positive relations with Turks today.

This view takes the position that the Armenian perceptions of a genocide are a "chosen trauma" that Armenians embrace but should supersede in order to have a healthier national identity. The resolution of the tension between Armenians and Turks therefore lies in a change in Armenian attitudes, an abandonment of their fixation on what they perceive as the great injustice and harm of 1915, toward a present- and future-focused understanding of themselves and the world. Thus, it is argued by some deniers, once Armenians as a group give up concern about their "chosen trauma," they will be able to have positive relations with Turks as a group. ${ }^{7}$

The second view accepts the clear historical evidence that the Ottoman government -and later Ataturk's nationalists -- committed genocide against Armenians. The onus for a change today in relations is not seen as one sitting on the shoulder of the Armenians, but rather on the contemporary Turkish state. The solution is simple: if Turkey gives up its denial campaign and instead acknowledges the historical veracity of the Armenian Genocide, then the major stumbling block to improved relations will be removed. The Turkish government and Turkish nationalists will no longer attack Armenians, threaten Armenians, and celebrate the past genocide through denial. ${ }^{8}$ Such an acknowledgment will be a de facto admission of wrong-doing, because everyone accepts that genocide is a great moral wrong and the denial campaign will be exposed as an attempted cover-up that will also be recognized as wrong. If an explicit apology can be added to recognition, this will be further help. With the changed attitude by the Turkish state and society toward Armenians, the path will be clear to the development of positive relations not tainted by past history or present exacerbation through denigration by denial.

First, acknowledgment of the Genocide will expose the violent, unjust nature of the Turkish exclusivist nationalism that has dominated since the CUP-era. This will open up Turkish society to other political approaches, especially a more liberal democratic alternative that includes strong respect for individual rights of all people in the society, including minority members, which will gain new credibility. It will also support a rethinking of attitudes toward minority groups such as Armenians and their treatment

\footnotetext{
${ }^{7}$ For a critical analysis of Itzkowitz' approach, see Theriault, "Universal Social Theory and the Denial of Genocide: Norman Itzkowitz Revisited," Journal of Genocide Research 3:2 (2001): 241-56.

${ }^{8}$ For this characterization of genocide denial, see Israel W. Charny, "A Contribution to the Psychology of Denial of Genocide," in Genocide \& Human Rights: Lessons from the Armenian Experience, special issue of Journal of Armenian Studies 4:1-2 (1992), pp. 289-306.
} 


\section{Journal of African Conflicts and Peace Studies}

by the Turkish state and society historically. Not only will the harms of the past be recognized but the demonization of minority groups, especially Armenians, that helped promote discrimination and violence against them, will be recognized as illegitimate. The positive contributions of minority groups as well as Turkish responsibility for harm to them will be recognized, which will support more pluralistic social and political structures in Turkey today.

If history cannot be changed, the attitudes that drove the Armenian Genocide can be abandoned in favor of a new approach that will respect Armenians and promote the well-being of all people in Turkey, including Armenians. This will carry over to Armenians around the world, fostering better relations with the Armenian Republic as well as the sizable Armenian diaspora. Turkey will improve politically and this will support the well-being of Armenians as well as Turks.

This second view is held by a range of people, including the apparent majority of thirdparty observers who recognize the Armenian Genocide, from genocide studies and other scholars to political leaders in the United States and elsewhere. It is also maintained by many progressive Turks who have taken the step of recognizing the Armenian Genocide or at least unjust mass violence against Armenians by the Ottoman government under the CUP. And, in recent years, it has come to be adopted by more and more Armenians, inside Turkey, in the Armenian Republic, and in the Armenian diaspora.

A third, hybrid approach has emerged as well, most notably in the work of Elazar Barkan. At some points, Barkan has embraced the first view, that in essence everything including the question of what happened in 1915 should be on the table for negotiation. ${ }^{9}$ At other points, Barkan appears to recognize that what happened in 1915 was genocide and that denial of this fact is the main obstacle to improved relations, though Armenians also need to be more open to Turkish attempts at improvement in relations and more sensitive to the difficulty Turks experience as they try to confront their past honestly. ${ }^{10}$ While these might seem to be different positions, they can also be viewed as different claims within an overall framework constructed by a scholar

${ }^{9}$ Timothy W. Ryback and Elazar Barkan, "A $\$ 12$ billion history lesson," International Herald Tribune, February 25, 2008.

${ }^{10}$ Barkan, Elezar "Can Memory of Genocide Lead to Reconciliation?" in The Armenian Genocide: Cultural and Ethical Legacies, ed. Richard Hovannisian (New Brunswick, NJ: Transaction, 2007), pp. 389-408. 


\section{Journal of African Conflicts and Peace Studies}

who understands that the Armenian Genocide did occur but at the same time who holds that the only way to resolve the conflict between Armenians and Turks is through an open dialogue process without preconditions, such as recognition of the Genocide.

In this way, Turks can come to deal with the history in their own way and time, while there can still be progress in Turkish-Armenian relations. Barkan seems to be assuming that eventually the truth will take hold in the process, and so even if Turks up front do not recognize the Genocide, eventually they will, satisfying what he perceives as an Armenian need for their suffering to be acknowledged by the perpetrator society, while not forcing the issue up front in a way that will alienate otherwise well-intentioned Turks. The resistance of some Turkish progressives to use the term "genocide" supports his claim that pressure for unhesitant full recognition up front could interfere with the long-term goal of bringing Armenians and Turks together. One can see as a strength of this approach that, if Turks do come to recognize the truth of the Armenian Genocide, they will have done so freely rather than under external pressure to confront the past. Turks going through such a process might thereby have a greater internal commitment to recognition and their recognition might be more meaningful than otherwise.

\section{Conflict or Domination? Recognizing the True Structure of Post-Genocide Intergroup Relations ${ }^{11}$}

It is tempting to examine the specific claims and projections of each of these approaches in order to evaluate the likelihood of each to effect the positive developments asserted for it. But these three models in fact share a common framework for conceptualizing Armenian-Turkish relations, whatever the differences in

\footnotetext{
11 The following analysis is draws on certain previous talks and articles, including "Justice or Peace? The Meanings, Potentials, and Pitfalls of Armenian-Turkish Dialogue," International Association of Genocide Scholars $5^{\text {th }}$ Biennial Conference, Irish Human Rights Center, National University of Ireland, June 8, 2003; "toward a New Conceptual Framework for Resolution: The Necessity of Recognizing the Perpetrator-Victim Dominance Relation in the Aftermath of Genocide", International Association of Genocide Scholars, 6th Biennial Conference, Boca Raton, FL, June 7, 2005; "Beyond Democratization: Perpetrator Societal Rehabilitation and Ethical Transformation in the Aftermath of Genocide," for the "The Armenian Genocide: Intersections of Scholarship, Human Rights, and Politics" symposium of the Greater Boston Armenian Genocide Commemoration, Watertown, MA, April 24, 2007; "Post-Genocide Imperial Domination," in Controversy and Debate: Special Armenian Genocide Insert of the Armenian Weekly, April 24, 2007, pp. 6-8, 26; and "From Past Genocide to Present Perpetrator-Victim Group Relations," in Commemorating Genocide: Images, Perspectives, Research (special Armenian Genocide issue of the Armenian Weekly, April 2008), pp. 2-6.
} 


\section{Journal of African Conflicts and Peace Studies}

their ideas of the specific problems and how to solve them. They assume that Armenians, as a relatively homogeneous grouping relative to relations with Turks, and Turks, as a relatively homogeneous grouping relative to relations with Armenians, are in what can properly be termed "conflict" or "tension." The specific terms are not essential, but the concept is: these approaches treat Armenians and Turks as two parties to a conflict or disagreement that can enter into some form of negotiative or dialogue process as roughly equal partners. Even if the past harm to Armenians is recognized and Armenians are not seen to share responsibility for the problems today, the present relationship is conceived as a mutual, symmetrical dichotomy between equal parties.

This view is inaccurate, and in a way that fundamentally undermines the effectiveness and validity of any such approach. The end of the genocide is generally not conceptualized fully; that is, in scholarly and political practice, the end of the killing is treated as a disengagement of the victims by the perpetrators. Interestingly, this is consistent with the exclusionist ideology of Turkification of Turkey that drove the Armenian Genocide: Armenians were to be extirpated from Turkey through their destruction. Post-genocide relations are thus treated as re-engagements by discrete groups who have been sundered by genocide. This is, in fact, how many contemporary Turks, especially progressives, understand the history of Armenian-Turkish relations -a kind of implicit acceptance of the terms of Turkish genocidal ultra-nationalism even if rejection of the ideology itself. They view new attempts at better relations to be an inviting of Armenians back into relations with Turks, an ending of the estrangement imposed by the Genocide and subsequent denial.

But a genocide is not an end to substantive perpetrator-victim relations, at least in cases where there are survivors. The process is more complex. The Armenian Genocide can be viewed as the middle phase of an overarching relationship of Turkish domination of Armenians. Turkish groups originally conquered Armenians hundreds of years before the Genocide and imposed the hierarchical millet system described above. This institutionalized the imperial conquest relationship of domination, complete with differential taxation as a form of tribute to the conquerors. By the late $19^{\text {th }}$ Century, this apartheid-type imperial system came into conflict with political currents among Armenians, Turks, and others calling for a transformation to modern statehood with homogeneous equal rights and participation for all those in Turkey. As oppression of and governmental and other violence against Armenians intensified, Armenians pushed more explicitly for basic civil rights within the Ottoman Empire. 


\section{Journal of African Conflicts and Peace Studies}

With the imperial system still intact, Abdul Hamid II used partial genocide to try to force the bulk of the Armenian population to remain in its subjugated position within Ottoman society. But with his overthrow and the establishment of a liberal, constitutional state in 1908, with the help of Armenians and other minority groups and recognition that they would be full participants in the new state, the institutional hierarchical structure of the old empire was jettisoned, and there was no longer the possibility of institutional internal subjugation of minority groups. Turks believed they had to be dominant in the new state, but the state was supposed to be egalitarian. While Kurds, who were considered to be assimilable because they were Muslim, could be folded into Turkish identity, the only solution, according to the Turkish point of view, that could resolve those two principles was elimination of Armenians and other major minority groups who were not considered assimilable. In this sense, the Armenian Genocide was a means of preventing the loss of domination over Armenians -- that is, of maintaining domination over Armenians -- in a changing context. The only form of domination remaining available was total domination through destruction of the victim group.

Effective elimination of Armenians from Turkey did not, therefore, signal an end to the relationship, but rather the maximization and consolidation of a powerful Turkish domination over Armenians. The post-genocidal relationship, in which Turkish state and society relate to Armenian survivors inside and outside of Turkey, is the result of this maximization of domination. The contemporary Armenian-Turkish relationship is a very asymmetrical power relation in which a mutual negotiative process is impossible: negotiation and dialogue would take place within a context of inequality and the results of an apparently equal process will preserve that inequality, that domination. Only through positive steps designed to change the material structure of the relationship can that domination be addressed.

This is not to say that recognition of the Armenian Genocide would not contribute to democratization of Turkey. It is possible that it would, by undermining support for ultranationalists. But this does not entail a more pluralistic society or a better relationship toward Armenians. On the contrary, egalitarianism within a group is quite compatible with the domination of outsiders. A change in the Turkish political culture could well benefit Turks, but if the anti-Armenian attitudes, practices, and power differential were not addressed, the same dominant relation would persist. One need look no further than the United States for evidence. Historically, race has functioned in the US as a way of separating out those who would not be allowed membership in the democratic system. Beyond the formal structures of democracy, there needs to be an ethical commitment in a society against domination of any group. In the United States, racist attitudes, institutions, and practices (slavery and genocide, respectively) toward both 


\section{Journal of African Conflicts and Peace Studies}

blacks and Native Americans meant that these groups were long denied -- and are in many ways still denied -- the benefits of an otherwise vibrant democracy.

\section{The Real Problem of Denial}

The domination relation is manifested in various ways, some which have already been discussed: for instance, Armenians in Turkey today are discriminated against generally and threatened and even assassinated for public statements about the Armenian Genocide, while Turkey continues to blockade Armenia.

The key element of the domination relation appears to be the denial campaign. For decades now, the Turkish denial has been the focus of efforts to achieve what is perceived as justice for the Genocide: as discussed above, it is believed that, if the perpetrator state and the world community recognize the Genocide, then the issue will be resolved. But this is a misperception. Denial is an injustice, but it is not the same injustice as the Genocide proper. It is a second, ancillary injustice. Even accepting the assertion that denial is the final stage of genocide does not mean that denial is the only result of genocide, for the material effects are separate and persist regardless of denial: the dead are still dead, expropriated property is still expropriated, political power in hands of the perpetrator group is still in their hands, and so on. What is more, an end to denial only stops further damage through denial; it does not address the harms inflicted through the active killing stage of a genocide.

Even if denial is seen as exacerbating the problem of the genocide itself, eliminating it merely stops further exacerbation without addressing the root problem. In itself, an end to denial does not end the domination relation of perpetrator group to victim group: that remains up until the point it is directly engaged. Indeed, if French philosopher Etienne Balibar's analysis of "neo-racism" is applied to the domination relationship of Turks over Armenians as structured by genocide and driven by a genocidal ideology, then the end of denial -- which is a symptom or form of expression of that domination relation produced through genocide - I will not mean an end to the underlying motives and structure producing it; on the contrary, they will remain intact and will be expressed through other means, in other forms. Thus, the Turkish government today might fully admit the Armenian Genocide yet the domination relation will be expressed in a new or newly-emphasized existent form. ${ }^{12}$ The only solution to the problem of

\footnotetext{
${ }^{12}$ Etienne Balibar, "Is There a 'Neo-Racism'?" in Race, Nation, Class: Ambiguous Identities, in Etienne Balibar \& Immanuel Wallerstein (Eds.) (New York: Verso, 1991), pp. 17-28.
} 


\section{Journal of African Conflicts and Peace Studies}

Armenian-Turkish relations is a direct addressing of the stark power imbalance of those relations.

An important question arises: why is an end to denial misrecognized as an end to domination and justice for the Armenian Genocide? The answer provides a key insight into the functioning of genocide denial. Denial is an impediment to better relations, but not simply because it obscures the truth and mocks the sensibilities of the victim community, however central these functions of denial are. ${ }^{13}$ Charny hints at the deeper problem in highlighting that denial is an assault on the very possibility of truth and the regard for truth we have. To go further, one can say that denial changes the relationship of victims, perpetrators, and others to truth. In fact, an active denial campaign, even once defeated, changes the framework through which the question of justice for a genocide and perpetrator-victim relations are considered. The pressure of denial changes the central issue of a given genocide from the harms done by the genocide itself to denial. Concern for the actual genocide gradually recedes, as overcoming denial comes to be the all-encompassing focus. This only makes sense: if a genocide is actively and effectively denied, then there cannot be consideration of anything else until the truth of the genocide is established. What is more, the effort of struggling against an extensive, well-funded, state-sponsored denial campaign is a tremendous drain on the victim community, combining resource depletion with the emotional costs of facing denigration and injustice through denial on a continuing basis. It is easy to understand why a victim group and committed third parties become engrossed in the battle against denial and easily come to see overcoming it as an end in itself, rather than a step toward engagement with the genocide proper. Denial changes the post-genocide goal from meaningful change in the power dynamics of the perpetrator and victim groups to the mere overcoming of denial. This is the coercive triumph of denial accomplished simply by its forceful assertion, regardless of its ultimate success. In this sense, denial is a contrived focus, a diversion. The only way to defeat denial -- to defeat its effects -- is to address the impact of the genocide directly, rather than merely challenging the denial. Achieving recognition can mean succumbing to denial and accepting the material political, social, and economic impact of the genocide.

It is not just that an exclusive focus on denial is a dead-end that will not properly address the outstanding problems of the Armenian Genocide. If the end of denial is taken as the resolution, this will justify not producing a real resolution of the Genocide issue. It is not just a failing path, but a harmful path that will prevent meaningful

${ }^{13}$ Charny, "A Contribution." 


\section{Journal of African Conflicts and Peace Studies}

change in Turkey and in Turkish-Armenian relations. In this way, "successfully" ending denial could actually consolidate and finalize the impact of the Genocide, because the terminus would be perceived as a significant step forward for Turkey relative to its genocidal past and denialist present and would have the widespread approval of Armenians.

\section{Toward a Meaningful Resolution of the Armenian Genocide Issue}

What is a meaningful resolution of this issue? Reduction of tensions between Armenians and Turks in itself is not, if it depends on acceptance by Armenians of the post-genocide status quo. In other words, a reduction of tensions, while a more comfortable situation than now exists, is not necessarily a just outcome. Addressing the impact of the Armenian Genocide requires changing the domination relation as well as redress for the material harms of the genocide, because these harms are the material features of the inequality imposed by the Genocide -- they changed the relative status, power, and wealth of Turks over Armenians. It is not that the Turkish and Armenian populations, territories, and powers should be equal, but that the effects of the Genocide in maximizing the inequality should be mitigated. Thus, lands and other wealth expropriated, as well as the benefits built on those for Turks in the years since the Genocide, should be returned. While the heightened demographic imbalance in the region produced through the mass killing of more than 1 million Armenians and forced assimilation of many others, with a severe and dramatic impact on the political and cultural viability of Armenians as a group, cannot be reversed, it can be somewhat mitigated by payment of some kind of balancing penalty by the perpetrator group. A monetary component can support the on-going reconstitution of the Armenian community, while Turkey could also support Armenians by assuming responsibility for their protection against aggression, supporting their economy through good trade relations and investment, and helping to repair Armenian dignity through sponsorship of strong public educational initiatives on the Genocide inside and outside of Turkey.

That is not to say that good relations are not important, but truly good relations free of domination depend on the foregoing steps. Good relations as dialogue are not a means to achieve resolution of the Armenian Genocide issue, but instead can only be the result of a just resolution that is entered into sincerely by Turkish state and society. There is no shortcut or easy way for Turks to have better relations than giving up their own dominance position, that is, giving up the material and political gains made through the Armenian Genocide and redressing the losses inflicted on Armenians. It requires sacrifice of unfairly gained material superiority. Return of Armenian lands depopulated through the Genocide, for instance, will at once demonstrate a rejection 
Theriault: Genocide, Denial, and Domination: Armenian-Turkish Relations from

\section{Journal of African Conflicts and Peace Studies}

of the ideology that excluded Armenians from possession of the lands they held in the Ottoman Empire and at the same time a rejection of raw power as the guarantor of continuing possession of those lands. Such a material sacrifice by the dominant group will effect or reflect a genuine conceptual transformation of Turkish relations with the Armenians. 